\title{
The Role of Feminist Health Humanities Scholarship and Black Women's Artistry in Re-Shaping the Origin Narrative of Modern, U.S. Gynecology
}

\author{
Rachel Dudley
}

check for

updates

Citation: Dudley, Rachel. 2021. The Role of Feminist Health Humanities Scholarship and Black Women's Artistry in Re-Shaping the Origin Narrative of Modern, U.S.

Gynecology. Humanities 10: 58. https://doi.org/10.3390/h10010058

Received: 16 December 2020

Accepted: 8 March 2021

Published: 23 March 2021

Publisher's Note: MDPI stays neutral with regard to jurisdictional claims in published maps and institutional affiliations.

Copyright: (C) 2021 by the author. Licensee MDPI, Basel, Switzerland. This article is an open access article distributed under the terms and conditions of the Creative Commons Attribution (CC BY) license (https:// creativecommons.org/licenses/by/ $4.0 /)$.
Women's and Gender Studies Department, The University of Toledo, Toledo, OH 43606, USA; rachel.dudley@utoledo.edu

\begin{abstract}
Between 1845-1849, twelve enslaved women in Montgomery, Alabama lived through prolonged, gynecologic experimentation at the hands of Dr. James Marion Sims. What happened, in his 16-bed backyard hospital, often begins the origin narrative of modern U.S. gynecology and how it developed into a discrete and international, Western, scientific field of medicine. Sims autobiography references three of these women, by their first names only: Anarcha, Lucy and Betsey. The research questions here are: what more can be known about these women's lives, their possible social networks and their cultural legacies? Further, what changes if the origin narrative of modern, U.S. gynecology begins with feminist health humanities scholarship and in the pages of black women's artistry? I discuss original research findings, involving the following primary source: an 1841 property deed, mentioning the first names of 7 other enslaved people owned by Sims. I, then, examine cotemporary U.S. feminist scholarly writing and artistic cultural representations, centering the lives of the women as important historical figures. Last, I conceptualize the notion of poetic ancestral witnessing within the work of the following three, twenty-first century, African American, poets: Bettina Judd, Dominique Christina and Kwoya Fagin Maples. These women published poetry collections on this history, between 2014 and 2018.
\end{abstract}

Keywords: medical history; modern U.S. gynecology; gender; race and slavery; medical experimentation; structural vulnerability; medical ethics; black feminism; poetry; memorial culture representation; health humanities; healing justice

\section{Introduction}

"What is monument to their legacy?"

-Natasha Tretheway, U.S. Poet Laureate and Winner of the Pulitzer Prize in Poetry for Native Guard (Tretheway 2006)

Using the frameworks of medical history, memorial culture studies and black feminism, this essay explores the poetics and politics of remembering and forgetting-in relation to the origin narrative of modern U.S. gynecology. In a series of prolonged medical experiments between 1845 and 1849, James Marion Sims accessed the bodies and nursing assistance of, structurally vulnerable, black enslaved women (see Cooper Owens 2017). Though there were sixteen beds in Sims' backyard hospital, only three of the women in this history are mentioned in Sims' life-writing, by their first names only: Anarcha, Lucy and Betsey. With these women, Sims invented the duckbill speculum and also perfected surgical procedures to suture vaginal fistulas, which helped grow his reputation and garner him international prestige (Sims 1884). Sims had an illustrious career and became a world-famous physician in the 19th-century. By the end of his life in 1883, Sims was becoming known as "the father of modern gynecology" and even "the architect of the vagina" (Barker-Benfield 1976).

In relation to this history, numerous 20th and 21st century community performers, humanities scholars and U.S., black women artists have engaged-quite imaginatively-in 
the politics and poetics of counter-hegemonic storytelling. They have worked to name and center the enslaved women patients in this history as "the mothers of modern gynecology" and to re-orient the telling of an important, international, socio-medical origin story (Daly 1978; Kuppers 2006; Wanzo 2009; Dudley 2016; Vedabtam 2017; Cooper Owens 2017). This essay highlights these works and emphasizes poetry—especially—as a site of social memory, ancestral legacy, and socio-medical meaning-making. In this kind of framing, we can ask: what changes if the origin narrative of modern, U.S. gynecology begins with feminist health humanities scholarship and in the pages of black women's artistry?

Significantly-I historically contextualize and theoretically analyze the work of three 21st century, African American poets, who have each published in this area, over the last decade. I also demonstrate how their work exists within a genealogy of feminist health humanities scholarship and communal health activism that has been ongoing for decades now. The writers and their poetry collections are as follows: Bettina Judd's Patient. Poems (Judd 2014); Dominique Christina's Anarcha Speaks: A History in Poems (Christina 2018); and Kwoya Fagin Maples' Mend Poems (Fagin Maples 2018). In the latter half of this essay, I thematically highlight the unique methodologies employed by Judd, Christina and Fagin Maples, which carve out space in memorial culture for "the mothers of modern gynecology" - through a politics of what I am calling poetic ancestral witnessing. In analyzing these works of poetry, I am able to explain the meaning and significance of this interdisciplinary, collaborative, and trans-temporal politics. In so doing, I demonstrate how their poetry helps reframe the origin story of modern U.S. gynecology. I also show how poetry is the appropriate medium to simultaneously hold and address historical traumas. It's also the appropriate medium to play with the complexities of scarce historical records, absences, voice and temporality, while also countering mainstream narratives about Sims' singular medical greatness.

Judd, Christina and Fagin Maples carve out important cultural space-by centering the women and highlighting their (possible) life histories and their (lasting) cultural legacies, as significant historical figures. These important historical figures, were placed in a complex situation, as bondswomen, as patients, and as trained nurses, in the first backyard women's hospital in the country (Barker-Benfield 1976; Daly 1978; Ojanuga 1993; Kapsalis 1997, 2002; Kuppers 2006, 2007; Judd 2011; Dudley 2012, 2016; Cooper Owens 2017). Feminist health humanities scholarship, community health activists and contemporary, African American poets have kept alive the cultural legacies of these supposedly "unknowable" and yet significant black historical figures. They all help us negotiate "social memory" in relation to this complex story in medical history, which continues to reverberate medically and culturally in various ways-well into the 21st century.

\subsection{On Continuing Relevance}

Issues of continued relevance in black feminist and women of color feminist perspectives include: sterilizations (largely of women of color) within spaces of containment such as prisons and immigration detainment facilities (Roth and Ainsworth 2015); pain and racial empathy gaps in clinical encounters (Trawalter et al. 2012); black women and contemporary infant and maternal mortality, during labor (Cooper Owens and Fett 2019). This history forces us to examine themes of history of science and medical ethics, contemporary issues with race and medical distrust as well as broader issues in the areas of gender, race and reproductive justice (see Roberts 1997). We can also use the history as an occasion to consider the important role of the health humanities in contemporary medical training and in reparative health justice work.

\subsection{On the Tradition of Intersectional Feminism, Poetry \& Healing Justice}

In Audre Lorde's famous and oft-cited essay, "Poetry is Not a Luxury," she encourages progressive communities to tap into non-patriarchal and non-Western ancestral ways of knowing (Lorde 1984). Lorde implies that these ways of knowing are rooted in emotional intelligence, spiritual and ecological awareness, ritual, community, body knowledge, intu- 
itive insight and creative imagination-all representing hidden forms of power (Lorde 1984, p. 37). Lorde, here, provides a starting point for healing justice work which has since gained greater articulation and urgency by movements on the ground within the last decade (see Page and Raffo 2013 and Astrea Lesbian Foundation for Justice, Healing Justice Report 2019).

After discussing the relationships between these ways of knowing and survival for marginalized communities, Audre Lorde reminds us about the function of poetry to process fears and as a source of hope, joy and optimism for social change. Lorde writes: "[F]or women, then, poetry is not a luxury. It is a vital necessity of our existence. It forms the quality of the light within which we predicate our hopes and dreams toward survival and change, first made into language, then into idea, then into more tangible action" (Lorde 1984, p. 37). It is in the vein of such a (trans-inclusive) black feminist tradition that this essay articulates a theory of U.S. black feminist poetics in relation to "the mothers of modern gynecology" and U.S. black women's 21st century, cultural representations. In order to contextualize the poetry under review here within a larger genealogy of scholarly and artistic praxis, I first orient readers by providing both medical history and cultural memory background on this topic. Significantly, this next part of the essay includes my original research findings that highlight black feminism and the politics of naming.

\section{Results \& Analysis}

\subsection{Medical History Background (Contextualizing the Poetry)}

Typically referenced only by their first names, as identified in Sims' life-writingAnarcha, Lucy and Betsey (plus up to nine other enslaved patients) were rotated in and out of un-anesthetized, vaginal surgeries by him, from at least 1845-1849. Significantly, recent artistry-scholarship, including mine and Bettina Judd's, identifies the full names of the women according to Sims' autobiography as: Anarcha Westcott, Lucy Zimmerman and Betsey Harris (Judd 2014; Dudley 2016). My research has also uncovered a property deed from 1841, which mentions first names of others enslaved people likely to have been in community with Anarcha, Lucy and Betsey. The poets discussed later in this essay also imagine the names of other people in community with the women. This includes the names Delia, imagined as a domestic servant and midwife-figure in the work of Fagin Maples and John, Anarcha's stillborn child imagined in the work of Dominque Christina.

Sims mentions having twelve beds in his clinic for enslaved women used in experiments and four for servants (a total of sixteen beds). From my research, the names provided in the property deed below may reveal more about the actual circle of other enslaved people who interacted with Anarcha, Lucy, Betsey and the others. They became an enslaved community network, brought together by a highly unique shared circumstance within a kind of "domestic servant and medical plantation" structure. The property deed states that Sims arranged to allow ownership (on official paperwork) of slaves, to his brother-in-law, Rush B. Jones, for the sum of five dollars. The condition was that the enslaved people mentioned below, and their future children were given as chattel property in a trust for Sims' wife Theresa, if Sims should happen to die first; Jones was the designated trustee (because women, of any race, could not own property at the time). The image of this document can be found below (Figures 1 and 2).

According to the document, Sims agreed to:

[H]ereby give grant bargain sell enfeoff and confirm into the said Rush B Jones the following negroe slaves together with the future increase of the females, to wit Abagail and her three children Amanda Martha and Minerva, Harriet and her children George and Emma.

(J Marion Sims 1841 Property Deed. Deed Records 1839-1841 Volume R LGM083, R05. Alabama Department of Archives and History)

To "enfeoff" meant to give property or land in exchange for service. While the enslaved people were technically enfeoffed to Rush B. Jones as the designated trustee, the deed indicates that they were kept by Sims: "[I]t is further understood as a condition in this 
instrument that the said negro slaves shall remain in my possession and under my control during my life without any accountability whatsoever on any part for the use thereof". (ibid) It was completed on 17 June 1841 and signed by Sims, Jones and two witnesses and the clerk representing the State of Alabama, Montgomery County. It could be the case that Sims was experiencing financial distress and created the arrangement in order to extract money from his ownership of Abagail, Harriet and each of their children (plus their future children). Speaking about the year 1840, Sims indicates in his autobiography: "we had no money and always lived from hand to mouth" (Sims 1884, p. 206). The question of what to do with his slaves during financially trying times would come up again as indicated by letter correspondences between he and his wife (Letters Between James and Theresa Sims. Box 666. J Marion Sims Papers. Southern Historical Collection. Louis Round Wilson Special Collections Library. The University of North Carolina at Chapel Hill). One letter between Sims and his wife, dated 29 December 1854, speaks of the need to "sell negroes" due to financial distress and it mentions two of the enslaved people by their first names: Cupe and Abby. (ibid)

What this information reveals are the names of other enslaved people owned by Sims as well as the likely possibility that Anarcha, Lucy and Betsey were in community with them, before Sims left for New York in 1853. Therefore, now we have the names: Anarcha Westcott, Lucy Zimmerman, Betsey Harris, Abagail Sims and her children Amanda, Martha and Minerva, as well as Harriet Sims and her children named George and Emma. We also have the names Cupe and Abby, which is a total of 12 out of 17 enslaved people owned by Sims during the period of 1841-1854 (depending on what arrangements Sims had for claiming the enslaved women he experimented upon on tax records and slave schedules). The point here is that black feminist perspectives help us understand that naming is about personhood. Names give a fuller sense of dignity to these women (and children) as significant historical actors.

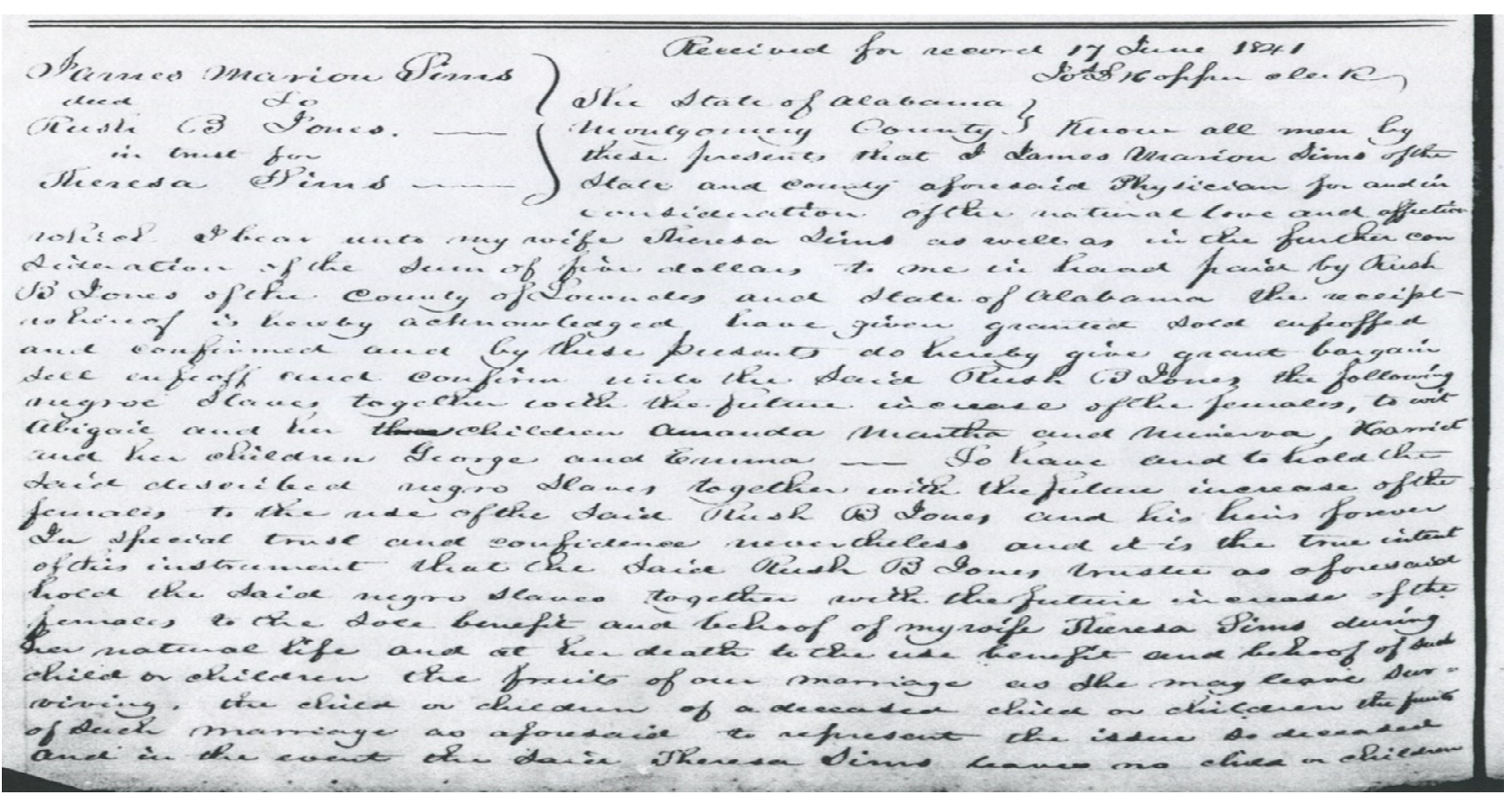

Figure 1. "James Marion Sims Property Deed to Rush B. Jones in trust for Theresa Sims" Montgomery, County 1841. Copyright of the Alabama Department of Archives and History.

On the women in his backyard hospital (and also with them) Sims invented the duckbill speculum and perfected protocols for the successful suturing of vesico-vaginal fistulas. It is necessary to note that these kinds of reproductive ailments-tears leading to incontinence, infection, odor and discomfort-were part and parcel with the demands of 
embodiment placed upon enslaved women, who were expected to reproduce as a condition of their bondage. Since Victorian notions of propriety did not apply to enslaved black women, Sims was able to use their structural vulnerability as a basis for medical research, innovation and entrepreneurial invention (see DuCille 1994).

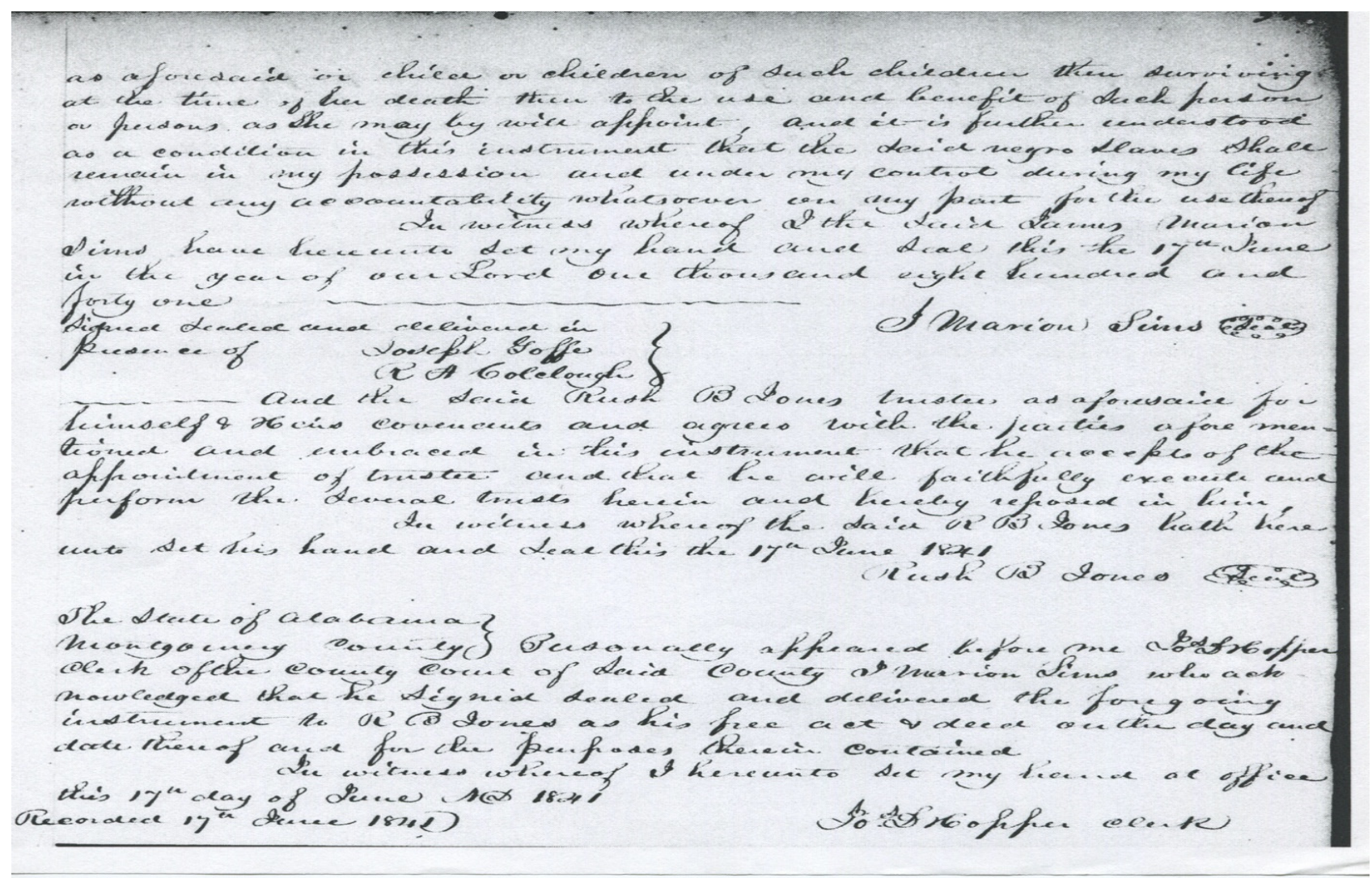

Figure 2. "James Marion Sims Property Deed to Rush B. Jones in trust for Theresa Sims" Montgomery, County 1841. Copyright of the Alabama Department of Archives and History.

After years of what he called "a series of philosophical experiment," Sims was able to document a procedure to successfully suture fistulas, using silver wire, by 1849 . He then published his results in both U.S. and international medical journals, all which helped to establish Western gynecology as a discrete branch of medical practice by the 1870s. Medical historian Deidre Cooper Owens is one notable humanities scholar who discusses the significance of these women as, skilled nurses who were trained by J. Marion Sims, after other white medical men stopped assisting him with his efforts (Cooper Owens 2017). Did they view him as a mad scientist at the time? Sims mentions the issue of abandonment specifically in the following newspaper excerpt (see Newspaper Clippings n.d., Box 666, Folder 6. J Marion Sims Papers. Southern Historical Collection. Louis Round Wilson Special Collections Library. The University of North Carolina at Chapel Hill.) (Figure 3):

I may mention the fact that when I first began my experiments, my professional brethren in Montgomery were all ready to come and help me, for they thought with me that I was on the eve of a great discovery; but, when they saw only failure after failure, they became tired of it, and in the third and fourth years I could get hardly any one to help me. During the last year my principal assistants were the patients; and they had always eagerly looked forward to the time of having their operations repeated, often contending with each other who should be next. All the operations were performed without an anesthetic. Indeed, I had been at work a year before the introduction of ether. 
Therefore, in the quote above, we learn that the women were their own nurses in the later years of his experimental series and he claims that they were eager to participate, right before mentioning that it was before the days of anesthesia. Therefore, if we accept Sims at his word here, then opium is one reason women might clamor for repeated vaginal surgeries without anesthesia. It is also worth asking, what if we do not take Sims at his word here (also see Wanzo 2009)? If we do not take Sims at his word here, then we might read this newspaper excerpt as an over-exaggeration of the women's eagerness as an attempt to absolve himself of guilt, or from claims that the enslaved women were mistreated or even tortured.

Using feminist health humanities perspectives, it's also important to mention how the phrase "they had always eagerly looked forward to the time of having their operations repeated" bears an eerie resemblance to victim blaming rhetoric such as "they were asking for it". Sims' phrasing (obviously) also obscures structural power relationships. However, it's also possible the women did desire a cure from the discomfort and stigma of the condition and were motivated to assist in finding a cure for a devastating condition (see Wall 2018). With that said, it is important to state that they were still not in a position to offer consent as enslaved people—due to social power arrangements.

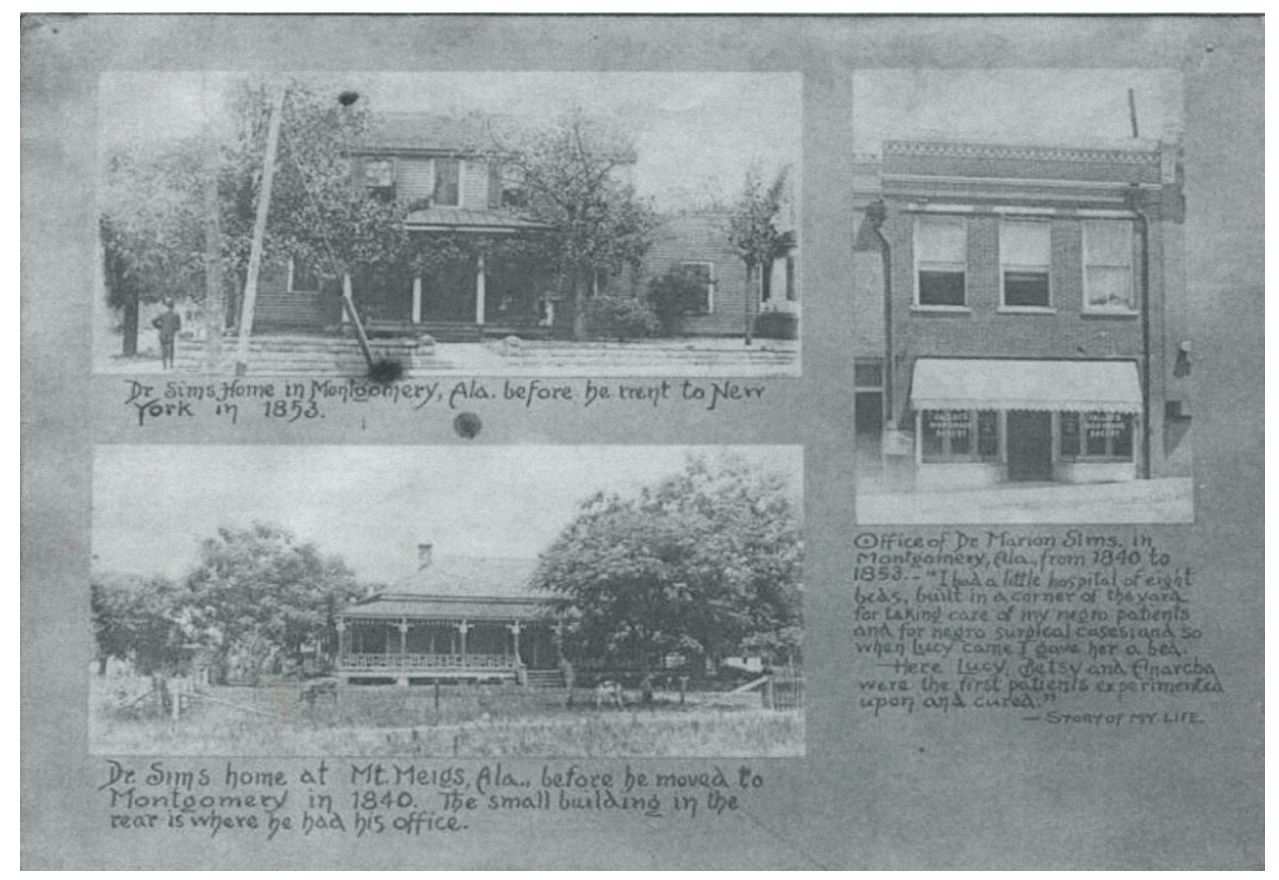

Figure 3. Image Homes of Dr. James Marion Sims in Montgomery and Mount Meigs, Alabama, and his office in Montgomery. Photograph is copyright of the Alabama Department of Archives and History, Photographs and Pictures Collection.

Sims later founded New York's first Women's Hospital, which was essentially an alms hospital where structurally vulnerable Irish immigrant women were also involved in gynecological and obstetric experimentation. By the 1880's Sims had become a worldrenowned medical showman, considered by many to be a paragon of white, male, Liberal subjectivity - and a symbol of U.S. medical greatness on the international stage. He served as president of the American Medical Association, was mourned widely at the time of his death in white U.S. newspapers and, as mentioned, has been referenced posthumously as "the father of modern gynecology" by various knowledge communities. He is lionized in history as a preeminent, American physician who made significant contributions to the advancement of medical knowledge "treating empress and slave alike".

Sims' work with numerous enslaved women in surgeries for fistula repair can be understood as existing at the center of multiple-larger-concentric spheres. These spheres 
involve the wider use of enslaved people in medical experimentation and scientific knowledge production and the management of health, illness and disability on U.S. southern slave plantations (see Boster 2015). These spheres also involve the shift from midwifery to medical birthing practices and tensions between black plantation medicine and white doctoring practices, during slavery in the nineteenth-century (McGregor 1998; Fett 2002).

The overlapping spheres of this story also involve Sims' backyard hospital as a positivist microcosm of "the birth of the clinic" itself (Foucault 1973). It's necessary to pause here, to consider the symbolism of a backyard hospital as a geographic space of experimentation and isolation, separate from the tobacco, sugar or cotton plantation (see McKittrick 2006). In an early iteration of this research project, I have also written about the backyard medical plantation as an isolated cultural space of knowledge production in the context of disability studies and disability history (Dudley 2012, also see Kuppers 2006).

Additionally, the concentric spheres in this history involve the nineteenth-century "calculus of suffering" that doctors had to make and the discovery and use of anesthesia in pain management for surgical procedures (Pernick 1983; Savitt 2007). These concentric spheres, of course, also involve dark histories of scientific racism and published false theoretical beliefs in the extraordinary ability of black people to endure physical pain at extraordinary levels (Cartwright [1851] 2004). The concentric spheres also involve the invention of (masculinized) medical instruments as technological advancements and the creation of a discrete medical specialization, using vulnerable populations. This is what feminist humanities frameworks allow us to see, while encouraging us to bear witness from marginalized perspectives.

Beyond this, the story is one of many medical history case studies relevant for biomedical ethics, reminding us about structures of power, geographies of separation and vulnerable segments of society. To the idea that Sims' was simply a man of his times, indeed he was, and he left a capacious and controversial legacy. The enslaved women too were women of their times, also people with capacious and enduring legacies. It's a complex historical story-one ripe for poetic interpretation.

Then, of course, there are the current health disparities and numerous issues with reproductive justice facing black women in the U.S. today. Therefore, with all of these concentric spheres at play in this story, I show how poetic ancestral witnessing addresses the silences and gaps in the archival records and reorients this mythological origin storycentering the women.

\subsection{Cultural Memory Background (Contextualizing the Poetry)}

Sculptural statues and other memorial dedications to J. Marion Sims started cropping up at the turn of the twentieth century. In fact, it was the "lost cause" type Southern Heritage group, Daughters of the American Revolution, who financed and unveiled the historical marker near Sims' birthplace in South Carolina. ("Ceremony in Lancaster to Pay Honor to Dr. J. Marion Sims (for his NY statue, see Figure 4)" Newspaper Clipping, Box 666, Folder 6. J Marion Sims Papers. Southern Historical Collection. Louis Round Wilson Special Collections Library. The University of North Carolina at Chapel Hill.) Public memorials and memorializing plaques dedicated to James Marion Sims include statues in five states (Alabama, Pennsylvania, New York, North Carolina and South Carolina), street names, a college dormitory, a fertility clinic in Ireland, endowed professorships, foundations, portraiture, entries in various state registries of historic places and an oil painting commissioned by Park-Davis pharmaceutical company.

Signs: Journal of Women and Culture in Society published a noteworthy special issue entitled, "Gender and Cultural Memory," where the editors explain the importance of feminist theory in relation to cultural memory studies (Hirsch and Smith 2002). They mention: "[t]heorizing cultural memory through the lens of feminism does not merely foreground the dynamics of gender and power. It also applies feminist modes of questioning to the analysis of cultural recall and forgetting" (Hirsch and Smith 2002, p. 3). Since at least the 1970's cultural/medical historians, feminist scholars and artists have been re-centering the 
lives and legacies of the enslaved women in this history and interrogating structures of race, gender and power in relation to the telling of this story (see for example Daly 1978; Washington 2006 or Finney 2013).

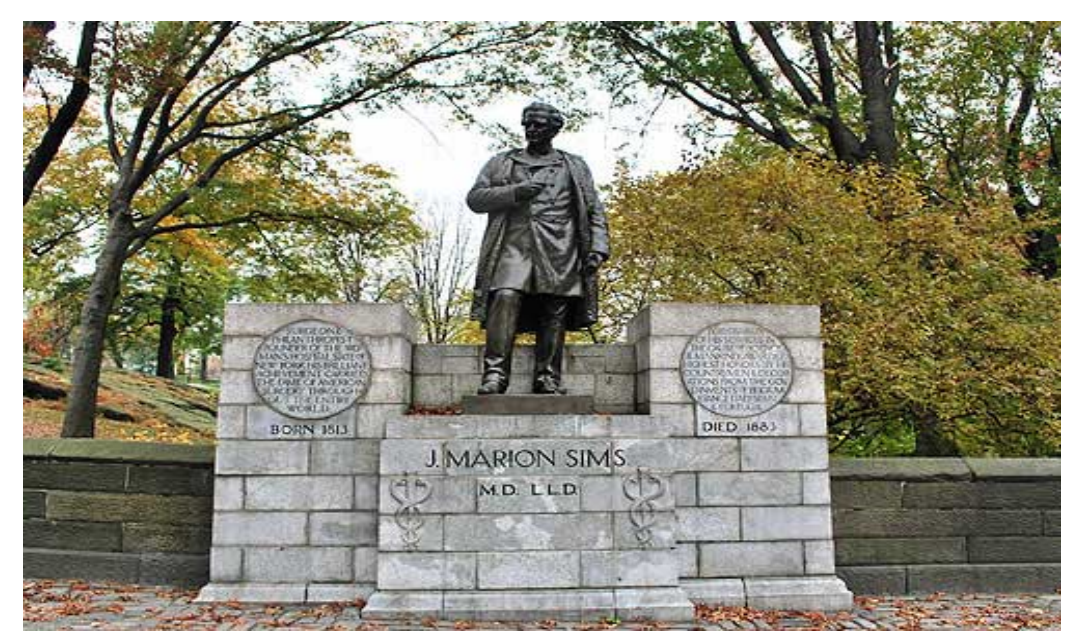

Figure 4. Image Dr. J Marion Sims Statue, New York's Central Park. Photograph (taken by author) 2013.

The last two decades have overseen a cultural and artistic groundswell of representation in relation to this history. This includes, for two important examples: The Anarcha Project, spearheaded by disability studies scholar Petra Kuppers; and The Body Ecology Performance Ensemble's womanist, theater of the oppressed-style, street performance work, led by Ebony Golden (see Boal 1979; Kuppers 2006; Cox 2008; Steichmann 2008; Wanzo 2009). These efforts have interrogated the tensions between history and cultural memory in relation to this important story.

This cultural groundswell, spearheaded by black women (and allies, some in other marginalized communities), has led to broader and more mainstream media representation of the enslaved women in this history, for example in HBO's Lovecraft Country, Episode 3, entitled Holy Ghost where the show alludes to experimentation on black Americans and references the names Lucy, Betsey and Anarcha directly (Green 2020).

This controversial and infamous medical history story continues to attract intrigue, dialogue and debate-most recently within the context of black political protest and narratives of U.S. history, national belonging and monument culture representations. In 2019-after decades of local community activism, artistry and black feminist scholarly attention-a replacement for the James Marion Sims monument in New York's Central Park, was commissioned. Sculptor Vinnie Bagwell was selected by the NYC Department of Cultural Affairs to create a public work, dedicated to the lives and legacies of the women in this history, which she named "Victory Beyond Sims (Figure 5)".

Significantly, this rich genealogy of re-framing and "re-remembering" the origin narrative of modern gynecology includes the poets and their poetry, under review in the remainder of this essay. This important medical history story represents a prime example of the negotiation between American mythology, cultural representation, social memory and the present (see Nora 1989).

After discussing the poet bios below, I will then demonstrate-through a close and comparative analysis-exactly how their poetry re-frames the origin story of modern gynecology. The poetry reimagines the possible life histories of the enslaved women, reorients their ancestral legacies and also addresses the contemporary politics of black women and 21st century health inequities. In other words, I show how these poets engage in poetic ancestral witnessing. 


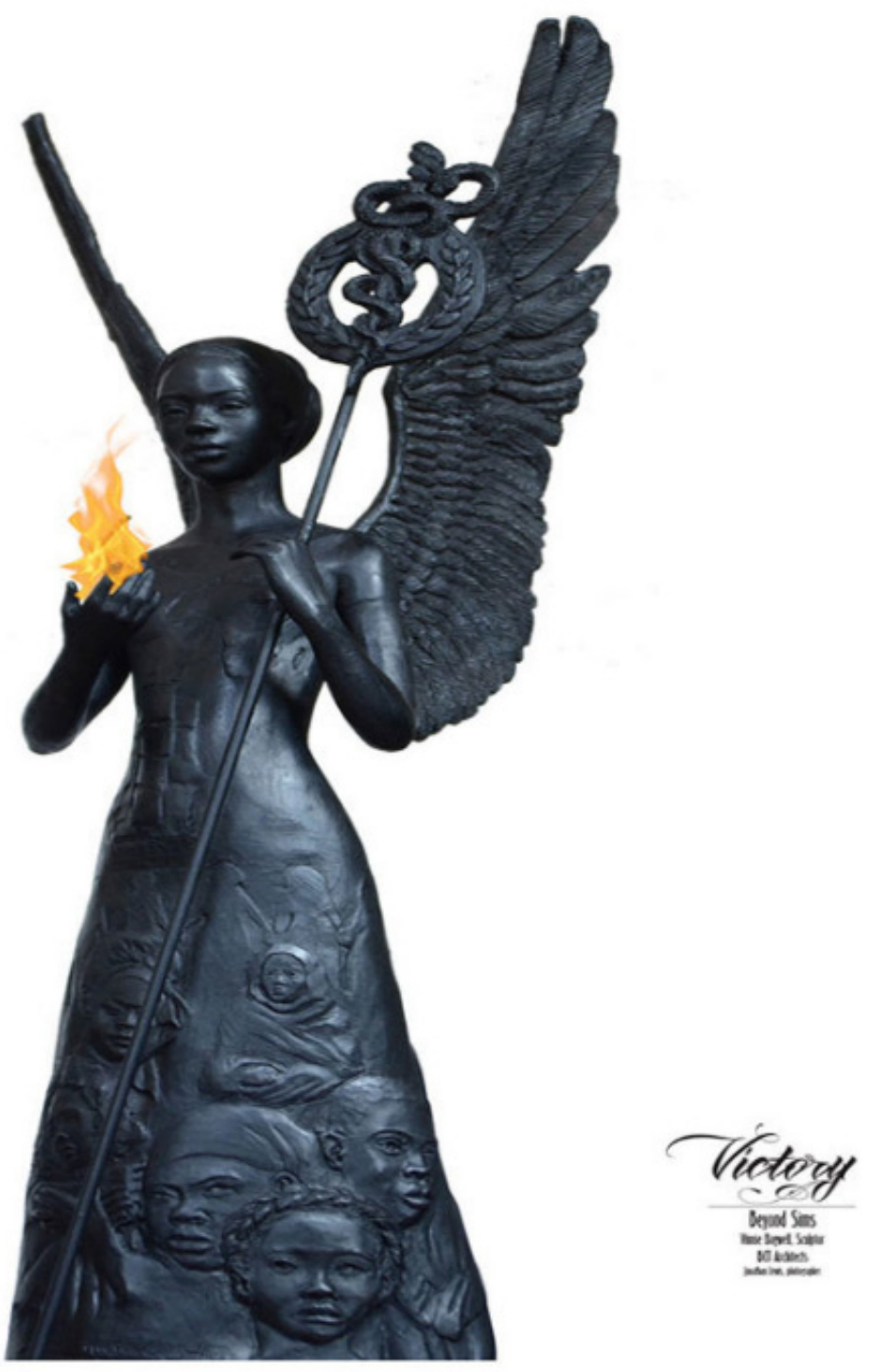

Figure 5. “Victory Beyond Sims" Rendering, by Sculpture Vinnie Bagwell Image Source: Artforum. com (accessed on 12 December 2020).

Importantly, a connection between black women's poetry and mobilization for health equity and wellness can be traced back to Audre Lorde's Cancer Journals (Lorde 1980) and A Burst of Light (Lorde 1988) and also to U.S. Poet, Civil Rights activist and memoirist, Maya Angelou's legacy project at Wake Forest University-The Maya Angelou Center for Health Equity.

\subsection{Poet Bios \& Notes on Style}

Since 2014, three African American poets have published groundbreaking books of poetry on the involvement of enslaved women in the development of modern gynecology. Bettina Judd, Ph.D., is an assistant professor of gender, women, and sexuality studies. She identifies as "an interdisciplinary writer, artist and performer whose research focus in on Black women's creative production and our use of visual art, literature, and music to develop feminist thought" (bettajudd.com, accessed on 12 December 2020). Judd has received numerous fellowships, including the prestigious Cave Canem Poetry Fellowship and she is a widely published scholar and poet. Cave Canem is a poetry foundation for African American Poetry, founded by Toi Derricotte and Cornelius Eady in 1996: "to remedy the under-representation and isolation of African American poets in the literary landscape" (cavecanempoets.org, accessed on 12 December 2020). There are numerous 
prolific and decorated Cave Canem poets and esteemed board members, including Pulitzer Prize winners Tyehimba Jess (2016) and Jericho Brown (2019).

Bettina Judd's debut book of poetry, Patient. Poems. explores the stories of numerous black women who served as "patients" and/or who were represented as racialized "oddities" in histories of modern capitalist entertainment, science and medicine. This includes poems about the following significant historical figures: Anarcha Westcott, Betsey Harris, Lucy Zimmerman, Joice Heth (see Reiss 2010; Saartjie Baartman (see Gilman 1985; Schiebinger 1993; Hammonds 1994; Crais and Scully 2010) and Henrietta Lacks (see Landecker 2007)).

Judd's inclusion of last names for Anarcha, Betsey and Lucy reflects scholarly attention to the archives, in relation to their white male, slave holder's last names which appear in Sims autobiography and in other historical records: including taxes, and slave schedules. In this way, Judd gives attention to naming conventions, dignity, humanity and personhood. The book cover for Patient includes a dark background with excerpts from J. Marion Sims' writing in grey, as well as sketched renderings of women's reproductive organs; this is all overlaid with a drawn rendering of a nude black woman's right arm, midsection and thigh, with a golden yellow symbol over the stomach, representing her uterus or maybe her gut (read intuition). Judd begins by putting her collection in conversation with a quote from esteemed and highly decorated Black American poet, Lucille Clifton.

Judd's style of writing includes a central metaphor of a haunting by various infamous black, female, historical figures following the narrator's own "ordeal with medicine" as a twenty-first century Black woman receiving healthcare in the United States. The narration in these poems plays with numerous themes, including: time disorientation, alternations in narrative voice (including the author's first-person narrative) and responses to actual historical documents and quotes, imagined in the first-person voices of these significant historical figures. Judd quite literally puts the women in conversation with the archives and moves beyond archival limitations to imagine what the archives cannot/do not reveal, due to gaps and omissions and the illegality of literacy for enslaved people. The narrator connects their own story as a patient in a traumatic medical encounter, with those of other black women in history, who famously (or infamously) served as patients.

In this way, Judd places the story of Anarcha Westcott, Lucy Zimmerman and Betsey Harris in a larger historical context which involves black women's bodies at the center of vast biomedical and capitalist enterprises-from the nineteenth-century "freakshow" to the development of modern gynecology, to the discovery of HeLa cells for scientific innovation, (and on and on)-all stories involving racialized and gendered exploitation and the diminishment of black women's pain. Judd's book organization includes sections of poems grouped by the following headings: Pathology; Use; Treason of the body is ... ; Parity. These decisions ground the arch of the text in the experience on the other side of "pathological" embodiment, particularly in relation to social constructions of pathology—rooted in 19th-century scientific sexism and racism. It ends by having readers consider the meaning of "parity" in this context.

Judd's work is extremely well-researched and anchored in the actual archival traces of these significant historical figures, through close readings of Sims and P.T. Barnum's autobiographies. The author includes scholarly footnotes to many of her poems or poem dedications, thus serving as ancestral witness, patient and researcher, allowing the historical figures to speak through her poems. Judd's narrator alludes to these women as occupying space, affectively, within her own body memory and embodiment. These historical figuresquite magically and literally - have been conjured, as an act of black ancestral witnessing. Each poet occupies this space of black feminist magical realism, akin to writers such as Octavia Butler, Toni Cade Bambara and Toni Morrison.

According to the book jacket, Dominque Christina is a National Poetry Series Winner for Anarcha Speaks: A History in Poems, which includes a forward by Tyehimba Jess, winner of a Pulitzer Prize. Christina's poetry is rooted in the black spoken word tradition and she has won the Women of the World Slam Championship twice and also served as the National Poetry Champion in 2011. Additionally, Christina has served as a teacher, at both 
the secondary and post-secondary levels and she has published four other works of poetry. The cover of her book, Anarcha Speaks, has a light cream background with the shadow of an African American woman's figure superimposed, featuring the title in burgundy and grey print. The cover imagery plays with the theme of ghosts, shadows and hauntings, a la Toni Morrison, Sharon Holland or Avery Gordon's works (Morrison 1987; Gordon 1997; Holland 2000).

Significantly, Christina's writing consistently explores the day to day "spiritual" dimensions of survival for these women as significant historical figures, existing in the total institution of experimental medical slavery. Christina imagines the women's philosophical questions about faith, their spirituality and the impact of trauma and opium addiction on the human psyche and soul. Decision on how to "contain" and organize this unruly historical story with continuing resonances is one each poet had to make. Christina's collection is organized around two sections, including: "She is a Woman Therefore She Remembers" and "The Juxtaposition of Experience".

Like Judd, Kwoya Fagin Maples is also a Cave Canem poet. She is from James Marion Sims birth state of South Carolina and she holds an MFA from the University of Alabama. According to the book jacket author biography, Fagin Maples' poetry has appeared in numerous anthologies and journals and she teaches creative writing at the Alabama School of Fine Arts. Her collection of poems on this subject entitled, Mend features a textured cream background with a grey coiled thread (or suture wire), appearing under the word "MEND" in reddish orange. Fagin Maples style of writing consistently incorporates specific and detailed allusions to the southern landscape, foliage and metaphors of fruits, nature and animals in relation to this history. Her collection is divided into a preface, followed by four roman numeral subsections which imagine the first encounters between Sims and the women, take readers through an imagining of their experiences and ends with the narrator's own birthing experience and reflections on joy as an act of resistance and reflections on black family caretaking, doulas, home birthing and black mothering.

\subsection{Poetic Ancestral Witnessing: Comparative Theme Analysis}

I am defining poetic ancestral witnessing as a poetic approach created by African American women and addressing the lives of populations on the margins of history, society and culture. It's a style of poetic writing that may take many forms, but that incorporates the following elements: magical realism, spirituality, historical research, transtemporality, non-linearity, embodiment, healing justice and social memory.

The sections below discuss the four common and significant themes found in the poetic work of Judd, Christina and Fagin Maples. These themes are as follows, in relation to poetic ancestral witnessing and the enslaved women as significant historical figures: (1) Naming Medical Knowledge Production, Centering the Enslaved Women and Imagining Their Life Narratives Based on Historical Research; (2) Exploring Opioid Addiction, Representing "Unspeakable" Pain E Trauma; (3) Thinking Though Metaphors of Ghosts a la Toni Morrison, Holding Space for Spirituality \& Expressing Ancestral Body Memory; (4) Sharing Personal Medical Testimonies, Articulating Current Relevance \& Poeticizing Healing Justice. Below, I will explore examples of each theme in these women's works.

2.5. Naming Medical Knowledge Production, Centering the Enslaved Women and Imagining Their Life Narratives Based on Historical Research

Each poet roots their work in the scant details available in the historical archives to paint powerful snippets of life narratives for these women as important historical figures. They were late teenagers when they were collected and taken away by Sims from their plantation communities, for his "philosophical experimentation". Enslaved women, of course, were expected to have numerous children in order to reproduce future generations of enslaved people, especially after the U.S. and British legal bans on of the African slave trade in 1807. The archives do not indicate how many children Anarcha, Betsey and Lucy (and the 9 others) may have had. However, Anarcha's first encounter with Sims is the result of a traumatic labor, which ended in a stillbirth, according to Sims autobiography. 
Therefore, exploring slavery and motherhood is a central theme in the work of each poet as a kind of re-orienting the narrative. The poets explore what it would have meant to become pregnant in the context of slavery and then to mourn and grieve the loss of a child-as a stillbirth in the case of Anarcha. For example, in the poem "Anarcha Makes Milk Anyway," Christina writes: "milk from these plain tits, milk!/Lets down hot on my dress, milk!/i making nector wit no baby". The poets also discuss the history of black women and breastfeeding white babies as mammy's or wet nurses, to fulfil domestic demands of slavery (see Wallace-Sanders 2008, 2019). In this case, the poets imagine the feelings and experiences of what it would have been like to be mourning the loss of your own child as an African American enslaved person and then be taken away to a new place with a rural doctor and (perhaps) expected to wet-nurse your slaver master's child. This is a scenario not outside the realm of possibilities for what the women may have experienced, compared to slave narratives and other historical research on slavery by African American women (Davis 1983; White 1985; Jones 1985; Hine et al. 1995). The poets each, in one way or another, explore the theme of black motherhood and breastfeeding, and the historical symbolism. In this way they imagine the human experience of the "grotesque" aspects of reproductive servitude.

Each poet finds a different way to explain the circumstances of the women's first encounters with Sims, realizing they would be taken into his charge and then how they would have coped with the shocking trauma to the body and the everyday realities of survival, over a long period of time. They also discuss everyday matters the women would have experienced, within the full spectrum of human emotion and feeling: joy, love, nostalgia, sadness, intrigue, spiritual reflection. Judd's work, rooted in historical archival research, demonstrates that Betsey came from a plantation of another doctor, Dr. Harris. Therefore, Judd, illustrates how Betsey may have been familiar with medical tools and, perhaps, overheard white, male, medical language. Interestingly, the poets also explore the role of the black midwife and black root medicine and healing practices the women would have known about (see Hurston 1994).

The poets place the women at the center of "scientific invention" and highlight their exposure to other medical physicians, medical students, midwives, root medicine, and each other as trained and knowledgeable medical resources. It's important to explain here that there is a direct mention of Sims' in relation to the enslaved women's exposure to midwifery, in a nineteen-century newspaper. Appearing in a newspaper tribute article, the quote below comes from another physician in Montgomery and a friend of J. Marion Sims, named Dr. William Baldwin:

I do not remember the precise year, but it was after he had acquired his great local reputation as a surgeon that he became deeply interested in working out what was at first known as his duck bill speculum, the vaginal speculum, which now bears his name and which was the foundation of the brilliant reputations which he has since achieved. He interested his medical friends in the country in hunting up for him different cases of uterine diseases which had resisted treatment in the hands of other physicians, and he was delighted when among these he could find a case of visico-vaginal fistula, that loathsome disease of women, which had previously been regarded as the opprobrium of surgery, and which physicians rather shunned than courted. He became enthusiastic in this as he was in all his pursuits and was not slow in finding cases of this disgusting disease, particularly among the slave population whose management in accouchement was generally confined to the ignorant midwives of their own color.

(Unknown Newspaper Clipping, found in the J. Marion Sims Papers, Box \#666. Louis Round Wilson Special Collections Library, University of North CarolinaChapel Hill)

Here we learn about the casual racial apathy from white men of letters, directed toward black midwifery and root doctoring as legitimate knowledge practices. Therefore, with this, we can also understand the tensions and transition between practices of midwifery, common among enslaved people, and medical treatments of reproductive health and 
birthing (McGregor 1998; Fett 2002; Schwartz 2010). It can be presumed that, just as most medical doctors in and around Montgomery knew what was going on with Sims' experiments, midwives and the larger enslaved population would have known as well. We can think about the idea of gossip in relation to how word would have traveled about Sims "series of philosophical experiment". What did other doctors in the town write about it and what are their accounts of what happened? Did Sims get mentioned in any of the local newspapers at the time? Did black newspapers anywhere in the U.S. South publish anything about medical experimentation or backyard hospitals? Can we look to addiction research and brain neurology to help us understand more about the women's lived experiences with opium addiction?

\subsection{Exploring Opioid Addiction, Representing Pain \& Trauma}

In relation to the last question in the previous paragraph, the themes of pain, trauma and addiction to opium are explored by each of the poets in this case study. The poets hold space for imagining how the body responds to these phenomena-and the corporal, mental and spiritual dimensions of endurance of prolonged surgical bodily trauma. The poets explore what happens to the human body, how it tenses, where the eyes might look in a room, where the mind goes and how one might dissociate. Through poetry, they are lending creative language to what Elaine Scarry articulates as the "unspeakability" of bodily pain, relating to torture (Scarry 1985). For example, Christina depicts symptoms of numbness as a response to trauma and the experience of opium addition in poems such as "Anarcha Dreams, OR How You Know You Ain't Gone" and "The Doctor Gives Her Opium After". Manifestations of trauma are infused everywhere throughout the poets works. This can be seen, again, for example in an allusion to disassociation where Anarcha is depicted as saying: "i go away from my own self" (Christina 2018, p. 57).

There is very little question these women were addicted to opium, which is what would have left them "clamoring" for participation in the experiments, as Sims suggests. Of course, opium is a highly addictive narcotic substance and years of (even controlled) usage would have certainly had significant physiological and psychological effects on the enslaved patients. As mentioned, when Sims speaks of the women being eager to participate in the surgical rotation, it is more likely that they were clamoring for an opium rush. While other historians take the possibility of opium addiction seriously, the poets allow us to imagine the realities of this in relation to a humanized experience. They explore, for examples, what the women's opium-induced dreams may have been like and what they may have done to cope, within their bodies, during the experimental procedures. These poets heavily rely on notions of the women's ghosts as a central metaphor for ancestral witnessing, and social memory work.

\subsection{Thinking Though Metaphors of Ghosts a la Toni Morrison, Holding Space for Spirituality \& Expressing Ancestral Body Memory}

Each poet engages with the central theme of these important historical women as shadow figures, ghosts and specters in different ways. For Dr. Bettina Judd, the women are imagined as ghosts who are present in the life of a poet as ancestral witness. In a 2013 interview with me for this research, Judd explains it as follows:

Bettina Judd: In my art, I imagine them more before they were captive to Sims and then after the experimentation, as I imagine them, they be-come ghosts. There's a poem where they're sitting in Johns Hopkins with me. So the way I think of them, really a lot around Anarcha, are these kind of ghosts who are constantly working with each other and other black women because they became nurses to each other. I imagine the way they may have nursed each other and been spiritual guides to each other and they do have a dynamic in my artwork. Betsey is the youngest so she feels hopeful. Lucy was older so she's a little more aloof and Anarcha is mad. So they have that dynamic with each other. I think it's really important to see them as agents in some way. I think of them as 
very capable women, as being really capable. Thinking that Betsey was already enslaved by a doctor, so thinking about what she already may have known or saw, like basic things that are connected to house-hold care. Did she handle instruments? Did she clean them? Betsey was Sims' first encounter with the speculum. She already knew medical equipment by seeing it in her enslaver's home or office. So I think of them as really capable. There's a way that they can be co-opted in see-ing them as co-conspirators with J. Marion Sims, but that's a survival strategy in so many ways. In my art, I imagine moments of them trying to acknowledge, identify and understand each other's pain. I imagine them as understanding themselves as being in a shared situation.

\section{(Judd 2013)}

In her very first poem in Patient, Judd remarks on the narrator's own experience: "I live in a haunted house/a house can be a dynasty, a bloodline, a body" (1). Like Judd, Fagin Maples also imagines an encounter between the poet as witness and the ghost of Anarcha. The poem "Meeting Anarcha" takes place while the poet works in her garden-present day. In this way, the poet is an ancestral witness and the historical women are still witnessing us as well. For Christina, it is not just Anarcha whose shadow looms in the American imagination but the poet imagines that Anarcha herself believed she was haunted at the time, during her experience in the nineteenth-century. Therefore, in this way, the poets deal with body memory, carrying trauma in the body and intergenerational racial-gender hauntings. In "Ghosts I Got," Christina writes in Anarcha's first person voice: "these ghosts I got/like to remember/like to wallop me/won't let none of it leave" (4). In this way, each poet plays with the tropes associating slavery with haunting and American social memory, al la Toni Morrison's literary genius in Beloved. The poets, as twenty-first century African American women, recover the past and also find themselves in this history. They also comment on contemporary racialized and gendered health inequities, while nodding toward a present and an Afro-futuristic vision built on redemption, joy, wellness and healing justice.

\subsection{Sharing Personal Medical Testimonies, Articulating Current Relevance E Poeticizing Healing Justice}

As mentioned previously, Civil Rights icon and poet, Audre Lorde is often credited with articulating radical notions of self-care as a revolutionary act in The Cancer Journals. There she famously, discusses her experiences with the United States healthcare system, as a self-defined "black, lesbian, feminist, mother, warrior, poet" dealing with a breast cancer diagnosis in the late 1970 s and early 80 s. She contributes to a black feminist emphasis on the body, embodiment, genre-bending cultural representation and health as the urgent and necessary political terrain of black feminist praxis. The body-as cultural and historical artifact-has always been at the center of black feminism (Lorde 1980; Hill Collins [1990] 2000; Wallace-Sanders 2002). The poets in this history take up this mantle powerfully, bearing witness to this history in ways that defy narrative conventions and invent new methodologies of conceptualizing time, history, embodiment and meaning-making in relation to the present moment. Importantly, they position themselves as researchers and still resist the distance of the detached, clinical gaze of archival language and they directly insert themselves into the narrative-in first person. They are in direct conversation with the archives in sharing their own personal testimonies in these poems.

Each of the three poets insert themselves, and their own personal medical testimonies into the narrative in the poems themselves, or in their dedications. Judd does this for example in her poem "In 2006, I Had An Ordeal With Medicine," while Christina speaks of her poetry as a kind of elegy and invokes the power of "ancestral writing" in her dedication to the historical women and to other lost in history, to "give them back the benefit of their names" (94). In Mend, Fagin Maples devotes all of section IV to her own experiences of birthing and black motherhood, as a kind of celebration, found for example in her piece about her daughter called "This Poem Resists with Joy" (69). These poems-while dealing 
with a deep well of human suffering and structural vulnerability-all manage to resist with joy. Be that in imagining the everyday joy of small resistance each important historical figure in this story may have found, or in the sorrow and joy of bearing witness through poetry-as a matter of healing justice for us all.

\section{Materials and Methods}

As this research involved both medical history and cultural memory, it comprises two different historical scopes. The first involves the collection of primary data from archival materials spanning from 1841 to 1856 in Montgomery, Alabama. This specific period is chosen because it ranges from several years before to several years after the medical containment the enslaved women experienced with Sims. Research began with three close readings of James Marion Sims' autobiography, A Story of My Life (Sims 1884), an early edition copy of which was checked out from the Robert W. Woodruff Library at Emory University.

Archival materials reviewed also include newspapers, personal letters, plantation ledgers, county and state records as well as census data about the slaveholders. This research was conducted between 2013-2016 at the Alabama Department of Archives and History and the Southern Historical Collection at the Louis Round Wilson Library, housed at the University of North Carolina, Chapel Hill. This research revealed details about the number of enslaved people owned by Sims, their genders and ages as well as some of their names from personal letters and an 1851 property deed.

The second historical frame deals with contemporary treatments of this history from 2002 to the present because this particular period frames and intense wave of feminist cultural criticism and representation, starting with scholarly work published by Terri Kapsalis in Skin Deep Spirit Strong: The Black Female Body in American Culture edited by Wallace-Sanders (2002) and ending with the removal Sims' statue in Harlem, New York, outside Central Park, in 2019. In this respect, I focus on representations of the enslaved women's legacies in poetry, through womanist performance art and through feminist scholarship. These representations are assessed as pivotal turning points, in contemporary representations and memorializing practices dedicated to the enslaved women as significant historical actors in this history.

Last, from a theoretical perspective informed by the frameworks of medical history, cultural memory studies and black feminism, I have historically contextualized and theoretically analyzed poetry as a site of counterhegemonic storytelling. This research demonstrates how interdisciplinary humanities approaches allow for a fuller, messier and more complex narrative, in relation to this important medical history. It is a story whose most important participants are marginalized women, without their own voices in the actual historical record. Ultimately, this essay has demonstrated the role of feminist health humanities scholarship and of black women's artistry in centering the women in this history. I've zeroed in on efforts highlighting the complexities of the enslaved women's possible life histories, while also exploring cultural representations honoring their medical, cultural and ancestral legacies.

Funding: This research received no external funding.

Institutional Review Board Statement: Ethical review and approval were waived for this study, due to meeting minimal risk research requirements, involving surveys/interviews.

Informed Consent Statement: Informed consent was obtained from all quoted interview participants involved in the study.

Data Availability Statement: Not applicable.

Conflicts of Interest: The author declares no conflict of interest. 


\section{Abbreviations}

Term

Black Feminism

Black Feminist Poetics

Feminism

Healing Justice

Intersectionality

Womanism/Womanist Tradition

Magical Realism

Poetic Ancestral Witnessing

\section{Definition}

Branch of feminism coined by the U.S.-based Combahee River Collective in 1974. Refers to active commitment to struggling against racial, sexual, heterosexual, and class oppression and the development of integrated analysis and practice based upon the fact that they major systems of oppression are interlocking. Centers black women's experiences in ending oppression for all. (Combahee River Collective [1977] 1995, p. 1)

Term coined by the author, in the context of this research. Refers to poetry written by women in the black diaspora, which centers a black feminist ethos in narrative conventions, style, content and/or form.

The movement to end sexism, sexist exploitation and oppression (Hooks 2000, p. 3)

A term created by southern, black feminist, social movement organizer Cara Page and the Kindred Southern Healing Justice Collective. Refers to a framework of how we can holistically respond to and intervene on generational trauma and violence, and to bring collective practices that can impact and transform the consequences of oppression on our bodies, hearts and minds (Page and Raffo 2013).

Term coined by Kimberle Crenshaw, which combines perspectives from black feminism and critical legal theory. Refers to the experience of facing multiple social inequalities at once, due to structural disadvantages related to marginalized identity categories (Crenshaw 1989, pp. 139-40).

Womanism is a term first defined by Pulitzer Prize-Winning, U.S. author Alice Walker, in her collection entitled In Search of Our Mother's Gardens. Refers to a social theory and/or tradition of feminism which centers the experiences of black feminists and feminists of color (Walker 1983, pp. xi-xii). A literary or artistic genre in which realistic narrative and naturalistic technique are combined with surreal elements of dream of fantasy (Oxford English Dictionary).

Term coined by the author. Refers to a poetic approach created by African American women and addressing the lives of oppressed populations on the margins of history, society and culture. It's a style of poetic writing that may take many forms, but that incorporates the following elements: magical realism, spirituality, historical research, trans-temporality, non-linearity, embodiment, healing justice and social memory.

\section{References}

Barker-Benfield, Graham John. 1976. The Architect of the Vagina. In The Horrors of the Half-Known Life: Male Attitudes Towards Women and Sexuality in the Nineteenth Century. New York and London: Harper and Row Publishing.

Boal, Augusto. 1979. Theatre of the Oppressed. New York: Urizen Books.

Boster, Dea H. 2015. African American Slavery and Disability: Bodies, Property and Power in the Antebellum South, 1800-1860. Studies in African American History and Culture Series. New York: Routledge.

Brown, Jericho. 2019. The Tradition. Port Townsend: Copper Canyon Press.

Cartwright, Samuel. 2004. Report on the Diseases and Peculiarities of the Negro Race. In Health, Disease and Illness: Concepts in Medicine. Edited by Arthur L. Caplan and James J. McCartney. Washington, DC: Georgetown University Press. First published 1851.

Christina, Dominique. 2018. Anarcha Speaks: A History in Poems. Boston: Beacon Press.

Combahee River Collective. 1995. A Black Feminist Statement. In Words of Fire: An Anthology of African-American Feminist Thought. Edited by Beverly Guy-Sheftall. New York: The New Press. First published 1977.

Cooper Owens, Deirdre. 2017. Medical Bondage: Race, Gender, and the Origins of American Gynecology. Athens: The University of Georgia Press. 
Cooper Owens, Deirdre, and Sharla M. Fett. 2019. Black Maternal and Infant Health: Historical Legacies of Slavery. Amereican Journal of Public Health 109: 1342-45.

Cox, Aimee Meredith. 2008. With Anarcha: A Meditative Diary on Personal Healing and Touching History Through Performance Practice. Liminalities 4: 1-19.

Crais, Clifton, and Pamela Scully. 2010. Sara Baartman and The Hottentot Venus: A Ghost Story and A Biography. Reprint edition. Princeton: Princeton University Press.

Crenshaw, Kimberle. 1989. Demarginalizing the Intersection of Race and Sex: A Black Feminist Critique of Antidiscrimination Doctrine, Feminist Theory and Antiracist Politics. University of Chicago Legal Forum 1: 139.

Daly, Mary. 1978. American Gynecology: Genocide by the Holy Ghost of Medicine. In Gyn/ecology: The Metaethics of Radical Feminism. Boston: Beacon Press.

Davis, Angela. 1983. Women, Race, and Class. New York: Vintage Books.

DuCille, Ann. 1994. The Occult of True Black Womanhood. Signs 19: 591-629. [CrossRef]

Dudley, Rachel. 2012. Toward an Understanding of the 'Medical Plantation' as a Cultural Location of Disability. Disability Studies Quarterly 32. [CrossRef]

Dudley, Rachel. 2016. Haunted Hospital: J. Marion Sims and the Legacies of Enslaved Women. Atlanta: Emory University.

Fagin Maples, Kwoya. 2018. Mend Poems. Lexington: University Press of Kentucky.

Fett, Sharla. 2002. Working Cures: Healing, Health and Power on Southern Slave Plantations. Chapel Hill: The University of North Carolina Press.

Finney, Nikky. 2013. The Greatest Sideshow on Earth. In The World Is Round. Evanston: Triquarterly Press.

Foucault, Michel. 1973. The Birth of the Clinic: An Archaeology of Medical Perception. New York: Random House Books.

Gilman, Sander. 1985. Difference and Pathology: Stereotypes of Sexuality, Race and Madness. New York: Cornell University Press.

Gordon, Avery. 1997. Ghostly Matters: Haunting the Sociological Imaginaition. Minneapolis: University of Minnesota Press.

Green, Dir. Misha. 2020. Lovecraft Country, Season 1, Episode 3, "Holy Ghost". New York: HBO Cable Television Company.

Hammonds, Evelyn. 1994. Black w(holes) and the Geometry of Black Female Sexuality. Differences: A Journal of Feminist Cultural Studies 6: 313-26.

Hill Collins, Patricia. 2000. Black Feminist Thought: Knowledge, Consciousness, and the Politics of Empowerment, 2nd ed. New York: Routledge. First published 1990.

Hine, Darlene Clark, Wilma King, and Linda Reed. 1995. We Specialize in the Wholly Impossible: A Reader in Black Women's History. New York: Carlson Publishing.

Hirsch, Marianne, and Valerie Smith. 2002. Feminism and Cultural Memory: An Introduction. Journal of Women in Culture and Society 28: 1-19. [CrossRef]

Holland, Sharon. 2000. Raising the Dead: Readings of Death and (Black) Subjectivity. Durham: Duke University Press.

Hooks, Bell. 2000. Feminism is for Everybody: Passionate Politics. Boston: South End Press.

Hurston, Zora Neale. 1994. Prescriptions of Root Doctors. In The Black Woman's Health Book: Speaking for Ourselves. New York: Seal Press, pp. 15-17.

Jess, Tyehimba. 2016. Olio. Seattle: Wave Books.

Jones, Jacqueline. 1985. Labor of Love, Labor of Sorrow: Black Women, Work, and the Family From Slavery to the Present. New York: Basic Books.

Judd, Bettina. 2011. The Researcher Discovers Anarcha, Betsey, Lucy. Meridians: Feminism, Race, Transnationalism 11: 238-39. [CrossRef]

Judd, Bettina. 2013. Dissertation Research. Telephone Interview (with Rachel Dudley), August 23.

Judd, Bettina. 2014. Patient. Poems. New York: Black Lawrence Press.

Kapsalis, Terri. 1997. Public Privates: Performing Gynecology From Both Ends of the Speculum. Durham: Duke University Press.

Kapsalis, Terri. 2002. Mastering the Female PelvisL Race and the Tools of Reproduction. In Skin Deep Spirit Strong: The Black Female Body in American Culture. Edited by Kimberly Wallace-Sanders. Ann Arbor: The University of Michigan Press.

Kuppers, Petra. 2006. Remembering Anarcha: Objection in the Medical Archive. Liminalities: A Journal of Performance Studies 4: 1-34.

Kuppers, Petra. 2007. The Anarcha Project: Performing in the Medical Plantation. Advances in Gender Research 11: 127-14.

Landecker, Hannah. 2007. Culturing Cells: How Cells Become Technologies. Cambridge: Harvard University Press.

Lorde, Audre. 1984. Poetry is Not a Luxury. In Sister Outsider: Essays and Speeches. Berkeley: The Crossing Press.

Lorde, Audre. 1980. The Cancer Journals. New York: Spinsters, Ink.

Lorde, Audre. 1988. A Burst of Light: Essays. New York: Firebrand Books.

McGregor, Deborah Kuhn. 1998. From Midwives to Medicine: The Birth of American Gynecology. New Brunswick and London: Rutgers University Press.

McKittrick, Katherine. 2006. Demonic Grounds: Black Women and Cartographies of Struggle. Minneapolis: University of Minnesota Press.

Morrison, Toni. 1987. Beloved. New York: Alfred A Knopf.

Newspaper Clippings. n.d. Box 666, Folder 6. J Marion Sims Papers. In Southern Historical Collection Louis Round Wilson Special Collections Library. Chapel Hill: The University of North Carolina.

Nora, Pierre. 1989. Between Memory and History: Les Lieux de Memoire. Representations 26: 7-24. [CrossRef]

Ojanuga, Durrenda. 1993. The medical ethics of the 'father of gynaecology', Dr J Marion Sims. Journal of Medical Ethics 19: 28-31. [CrossRef] [PubMed]

Page, Cara, and Susan Raffo. 2013. Healing Justice at the US Social Forum: A Report from Atlanta, Detroit \& Beyond. Available online: https:/ / www.scribd.com/document/147620375/Healing-Justice-at-the-US-Social-Forum-1 (accessed on 12 December 2020). 
Pernick, Martin S. 1983. The Calculus of Suffering in Nineteenth-Century Surgery. Hastings Center Report 13: 26-36. [CrossRef] Reiss, Benjamin. 2010. The Showman and The Slave: Race, Death and Memory in Barnum's America. Cambridge: Harvard University Press. Roberts, Dorothy. 1997. Killing the Black Body: Race, Reproduction, and the Meaning of Liberty. New York: Pantheon Books.

Ross, Loretta, Erika Derkas, Whitney Peoples, Lynn Roberts, and Pamela Bridgewater, eds. 2017. Radical Reproductive Justice: Foundations, Theory, Practice. New York: Feminist Press.

Ross, Loretta, Elena GutiŽrrez, Marlene Gerber, and Jael Silliman. 2016. Undivided Rights: Women of Color Organize for Reproductive Justice. Chicago: Haymarket Books.

Ross, Loretta, and Rickie Solinger. 2017. Reproductive Justice: An Introduction. Oakland: University of California Press.

Roth, Rachel, and Sara Ainsworth. 2015. "If They Hand You a Paper, You Sign It": A Call to End the Sterilization of Women in Prison, 26 Hastings Women's Law Journal, Vol. 26, No. 1. Available online: https://repository.uchastings.edu/hwlj/vol26/iss1/3/ (accessed on 20 March 2021).

Savitt, Todd. 2007. Race and Medicine in Nineteenth- and Early-Twentieth-Century America. Kent: Kent State University Press.

Scarry, Elaine. 1985. The Body in Pain: The Making and Unmaking of the World. New York and Oxford: Oxford University Press.

Schiebinger, Londa. 1993. Nature's Body: Gender in the Making of Modern Science. New York: Routledge University Press.

Schwartz, Marie Jenkins. 2010. Birthing a Slave: Motherhood and Medicine in the Antebellum South. Cambridge: Harvard University Press.

Sims, James Marion. 1884. The Story of My Life. New York: D. Appleton and Company.

Steichmann, Jay. 2008. The Anarcha Project. The Anarcha Anti-Archive. Liminalities: A Journal of Performance Studies. Available online: http:/ /liminalities.net/4-2/anarcha/ (accessed on 30 November 2013).

Trawalter, Sophie, Kelly M. Hoffman, and Adam Waytz. 2012. Racial Bias in Perceptions of Others' Pain. PLoS ONE 7: e48546. [CrossRef] [PubMed]

Tretheway, Natasha. 2006. Native Guard. Boston and New York: Houghton Mifflin Company.

Vedabtam, Shankar. 2017. Remembering Anarcha, Lucy and Betsey: The Mothers of Gynecology. Hidden Brain Radio Show, National Public Radio. Hosted by Shankar Vedabtam, featuring Vannessa Northington Gamble, M.D. and Bettina Judd. Available online: https: / / www.npr.org/transcripts/513764158 (accessed on 20 February 2017).

Walker, Alice. 1983. Womanism. In In Search of Our Mother's Gardens: Womanist Prose. San Diego: Harcourt Brace Jovanovich.

Wall, Lewis L. 2018. Tears for My Sisters: The Tragedy of Obstetric Fistula. Baltimore: John Hopkins University Press.

Wallace-Sanders, Kimberly. 2002. Skin Deep, Spirit Strong: The Black Female Body in American Culture. Ann Arbor: University of Michigan Press.

Wallace-Sanders, Kimberly. 2008. Mammy: A Century of Race, Gender, and Southern Memory. Ann Arbor: University of Michigan Press.

Wallace-Sanders, Kimberly. 2019. Curator. In Framing Shadows: Portraits of Nannies from the Robert Langmuir African American Photograph Collection. Atlanta: Woodruff Library, Emory University, Available online: https://exhibits.libraries.emory.edu/ framing-shadows / (accessed on 20 March 2021).

Wanzo, Rebecca. 2009. In the Shadows of Anarcha. In This Suffering Will Not Be Televised. New York: Suny Press.

Washington, Harriet. 2006. Medical Apartheid: The Dark History of Medical Experimentation on Black Americans from Colonial Times to the Present. New York: Harlem Moon Press.

White, Deborah Gray. 1985. Ar'n't I a Woman? Female Slaves in the Antebellum South. New York: W.W. Norton and Company. 